\title{
Brachyolmia-amelogenesis imperfecta syndrome
}

INSERM

\section{Source}

INSERM. (1999). Orphanet: an online rare disease and orphan drug data base.

Brachyolmia-amelogenesis imperfecta syndrome. ORPHA:2899

Autosomal recessive brachyolmia-amelogenesis imperfecta syndrome is an exceedingly rare form of brachyolmia (see this term), characterized by mild platyspondyly, broad ilia, elong ated femoral necks with coxa valga, scoliosis, and short trunked short stature associated with amelogenesis imperfecta (see this term) of both primary and permanent dentition. 